\title{
Preparation of cow milk yoghurt blended with soymilk
}

\author{
R.U. TALEKAR, R.R. SHELKE, R.V. KARCHE AND A.V. BHAGAT
}

\begin{abstract}
Yoghurt was prepared from cow milk blended with soymilk in the Dairy Technology laboratory of Department of Animal Husbandry and Dairy science, Dr. Panjabrao Deshmukh Krishi Vidyapeeth, Akola (M.S.). Yoghurt prepared with different combinations of cow milk and soymilk as 100:00 $\left(\mathrm{T}_{1}\right), 75: 25\left(\mathrm{~T}_{2}\right), 50: 50\left(\mathrm{~T}_{3}\right), 25: 75\left(\mathrm{~T}_{4}\right)$ and 00:100 ( $\left.\mathrm{T}_{5}\right)$ was evaluated for various sensory attributes and the results revealed that overall acceptability scores obtained were $96.03,91.34,87.58,83.33$ and 80.33 for the treatment $\mathrm{T}_{1}, \mathrm{~T}_{2}, \mathrm{~T}_{3}, \mathrm{~T}_{4}$ and $\mathrm{T}_{5}$, respectively. Fat, $\mathrm{SNF}$, acidity and $\mathrm{TS}$ of yoghurt samples were decreased normally while protein and moisture increased with increase in levels of soymilk. The per kilogram production cost of yoghurt was decreased with increase in soymilk percentage i.e. Rs. 37.63 for (100\% cow milk yoghurt), Rs. 21.38 (50:50 cow milk and soymilk) and Rs. 15.25 for 100 per cent soymilk. It was found that yoghurt prepared from various combinations upto 50 per cent cow milk and 50 per cent soymilk was most acceptable.
\end{abstract}

KEY WORDS : Yoghurt, Cow milk, Soymilk

HOW TO CITE THIS PAPER : Talekar, R.U., Shelke, R.R., Karche, R.V. and Bhagat, A.V. (2015). Preparation of cow milk yoghurt blended with soymilk. Res. J. Animal Hus. \& Dairy Sci., 6(1) : 32-36.

\section{MEMBERS OF RESEARCH FORUM}

Address for correspondence :

R.V. Karche, Department of Animal Husbandry and Dairy Science, Mahatma Phule Krishi Vidyapeeth, Rahuri, AHMEDNAGAR (M.S.) INDIA

Email : ranjitkarche89@gmail.com

Associated Authors':

R.U. Talekar, R.R. Shelke and A.V. Bhagat, Deparment of Animal Husbandry and Dairy Science, Dr. Panjabrao Deshmukh Krishi Vidyapeeth, Akola (M.S.) INDIA 